Article

\title{
The Desulfurization of Magnetite Ore by Flotation with a Mixture of Xanthate and Dixanthogen
}

\author{
Jun Yu, Yingyong Ge* and Xinwei Cai \\ School of Resources and Environment Engineering, Wuhan University of Technology, Wuhan 430070, China; \\ yuju198521@whut.edu.cn (J.Y.); 144583@whut.edu.cn (X.C.) \\ * Correspondence: geyy@whut.edu.cn; Tel.: +86-27-8747-1645 \\ Academic Editor: Kota Hanumantha Rao
}

Received: 27 May 2016; Accepted: 4 July 2016; Published: 8 July 2016

\begin{abstract}
The contamination of sulfur emanating from pyrrhotite in magnetite concentrates has been a problem in iron ore processing. This study utilized froth flotation to float pyrrhotite away from magnetite using collectors of xanthate and dixanthogen. It was found that xanthate or dixanthogen alone could not achieve selective separation between pyrrhotite and magnetite in flotation. A high loss of magnetite was obtained with xanthate, while a low desulfurization degree was obtained with dixanthogen. It was interesting that a high desulfurization ratio was achieved with little loss of magnetite when xanthate was mixed with dixanthogen as the collector. The synergistic effect of the mixed collector on pyrrhotite was studied by electrokinectic studies and FTIR measurements. It was found that xanthate was the anchor on pyrrhotite and determined its selectivity against magnetite, while dixanthogen associated with xanthate, enhancing its hydrophobicity. This study provides new insights into the separation of iron minerals.
\end{abstract}

Keywords: pyrrhotite; mixed collectors; flotation; synergetic effect

\section{Introduction}

In recent decades, there has been an ever-increasing demand for iron ore because of its great demand in metallurgy industries [1]. Due to the depletion of high quality iron ores, complex ultrafine iron ores with a high content of impurities, such as sulfur, have been processed [2]. Pyrrhotite $\left(\mathrm{Fe}_{1-x} \mathrm{~S}\right)$ is a kind of common sulfide which exists in magnetite ore as an associated mineral with little industrial value. The contamination of sulfur emanating from pyrrhotite in magnetite concentrates has been a problem in iron ore smelting process. However, the magnetic separation of pyrrhotite from magnetite is problematic, due to their similar magnetic property and magnetic flocculation between pyrrhotite and magnetite [3].

Flotation has been commercially used as a method for removing pyrrhotite from magnetite for high sulfurous iron ores [4]. In this process, pyrrhotite as a primary impurity is separated from iron ore using typically potassium butyl xanthate as the primary collector. The flotation process normally adds copper sulfate as an activator which could accelerate the flotation rate of pyrrhotite. The flotation is conducted at the natural $\mathrm{pH}$ of the milled ore which may vary between 7.5 and 9 but it is typically closer to the higher value [5]. However, in the practice of iron ore flotation, the loss of valuable mineral in tailings is the major problem confronting the iron ore industry. Thus, the reagent suit is formulated to create the appropriate chemical environment for effective separation. The collector suit is often tuned to use mixed collectors to enhance both grade and recovery of the concentrate, and to lower cost [6].

The use of dissimilar surfactant mixtures can have a synergistic advantage over the use of individual surfactants [7-11]. The influence of nonionic reagents on anionic collector flotation of calcium minerals was investigated [12]. The addition of nonionic reagents to anionic collectors 
enhanced the flotation separation efficiency of calcium minerals due to hydrophobic chain interactions and reduction of electrostatic repulsion between ionic head groups that are shielded from each other by the nonionic surfactant molecules. A process involving the use of mixed anionic and cationic collectors for muscovite mica was studied [13]. The flotation recovery could be enhanced using a mixture of dodecylamine acetate with sodium oleate. The adsorption of both the cationic and anionic collectors was enhanced due to co-adsorption. A combined cationic (amine) and anionic collector (sodium xanthate) was also reported to be effective for the flotation of zinc oxide at pH 11 [14].

In this study, attempts were made to enhance the selective separation of pyrrhotite from magnetite. Flotation experiments were conducted with different collector suits (xanthate, dixanthogen, and their mixture). The synergetic effects of mixing dixanthogen with xanthate were also studied by zeta potential and infrared spectroscopic measurements.

\section{Materials and Methods}

\subsection{Materials}

A magnetic concentrate was obtained from Baogang plant (Neimeng, China). The principal research sample was the magnetic product of the primary iron ore containing $65.10 \% \mathrm{Fe}$. The results of chemical analyses of this sample are given in Table 1 and the chemical compositions of which are given in Table 2. From Tables 1 and 2, it is observed that the magnetite, pyrrhotite, quartz, and calcite are the main compositions in this sample.

Table 1. Chemical analysis results of magnetic concentrate (mass fraction, \%).

\begin{tabular}{ccccccccccc}
\hline Composition & $\mathrm{TFe}^{*}$ & $\mathrm{Fe}_{2} \mathrm{O}_{\mathbf{3}}$ & $\mathrm{SiO}_{2}$ & $\mathbf{A l}_{\mathbf{2}} \mathbf{O}_{3}$ & $\mathbf{K}_{\mathbf{2}} \mathbf{O}$ & $\mathbf{C a O}$ & $\mathbf{M g O}$ & $\mathbf{P}$ & $\mathbf{S}$ & $\mathrm{TiO}_{2}$ \\
\hline wt \% & 65.10 & 92.35 & 3.54 & 0.35 & 0.026 & 1.68 & 0.25 & 0.049 & 1.64 & 0.10 \\
\hline \multicolumn{1}{c}{ * TFe: Total iron. }
\end{tabular}

Table 2. Analysis of iron chemical phase in the magnetic concentrate (mass fraction, \%).

\begin{tabular}{ccccccccc}
\hline Composition & Magnetite & Pyrrhotite & Pyrite & Quartz & Calcite & Dolomite & Phyllite & Barite \\
\hline wt $\%$ & 86.88 & 4.32 & 0.23 & 3.56 & 2.56 & 1.22 & 0.47 & 0.75 \\
\hline
\end{tabular}

The pure pyrrhotite mineral and magnetite used in this study was provided by Baogang Mine, Neimeng Province, China. The mineral compositions of pure pyrrhotite and magnetite were analyzed by Mineralogical Liberation Analysis (MLA). The analysis results in Tables 3 and 4 show that it was of high purity with minor impurities in pyrrhotite and magnetite. The lumps of pyrrhotite and magnetite were crushed and ground to a particle size less than $74 \mu \mathrm{m}$ in a ceramic ball mill. The powder of $-74 \mu \mathrm{m}$ was further ground to $-2 \mu \mathrm{m}$ for zeta potential and FTIR experimental studies. The mineral sample was stored in a glass drying dish for further investigations.

Table 3. Minerals compositions of pure pyrrhotite.

\begin{tabular}{ccccccc}
\hline Minerals & Pyrrhotite & Chalcopyrite & Limonite & Dolomite & Quartz & Mica \\
\hline wt $\%$ & 98.51 & 0.32 & 0.10 & 0.35 & 0.08 & 0.40 \\
\hline
\end{tabular}

Table 4. Minerals compositions of pure magnetite.

\begin{tabular}{ccccccc}
\hline Minerals & Magnetite & Quartz & Calcite & Ankerite & Phyllite & Siderite \\
\hline wt $\%$ & 97.12 & 0.84 & 0.45 & 0.33 & 0.41 & 0.22 \\
\hline
\end{tabular}


The collector used in the tests was sodium butyl xanthate (NaBX, $\left.\mathrm{CH}_{3} \mathrm{CH}_{2} \mathrm{CH}_{2} \mathrm{CH}_{2} \mathrm{OCS}_{2} \mathrm{Na}\right)$ supplied from Zhuzhou Flotation Reagents Plant (Zhuzhou, China). Dibutyl dixanthogen $\left((\mathrm{BX})_{2}\right)$ was used as a collector which was synthesized with xanthate and hydrogen peroxide. The Dibutyl dixanthogen was purified by extraction. Sodium fluosilicate $\left(\mathrm{Na}_{2} \mathrm{SiF}_{6}\right)$ was used as an activator. Sodium carbonate, sulfuric acid, hydrochloric acid, and sodium hydroxide of analytical grade from Kemiou Chemical Reagent Co. Ltd. (Tianjin, China) were used to regulate the $\mathrm{pH}$ of the system. Pine oil has been used as the frother. Distilled water was used in all the experiments.

\subsection{Methods}

\subsubsection{Grinding and Flotation Experiments}

The grinding was carried out at room temperature using tap water. $400 \mathrm{~g}$ magnetic concentrate sample at $66.7 \%$ solid density was ground in a ball mill to gain an $85 \mathrm{wt} \%$ passing size of $74 \mu \mathrm{m}$. The mill discharge was transferred to a $1.0 \mathrm{dm}^{3}$ XFD-type laboratory flotation cell. The air flow rate was $45 \mathrm{dm}^{3} / \mathrm{h}$ and the agitation speed was $1800 \mathrm{rpm}$. The flotation experiments were carried out in accordance with the flow sheet shown in Figure 1. The activator $\left(\mathrm{Na}_{2} \mathrm{SiF}_{6}\right)$ was added to the slurry and conditioned for $15 \mathrm{~min}$. The $\mathrm{pH}$ regulator $\left(\mathrm{H}_{2} \mathrm{SO}_{4}\right.$ or $\left.\mathrm{Na}_{2} \mathrm{CO}_{3}\right)$, collector, and pine oil were added successively to the slurry and conditioned for $3 \mathrm{~min}, 3 \mathrm{~min}$, and $1 \mathrm{~min}$, respectively before flotation. The flotation tailing (froth product) was collected for $3 \mathrm{~min}$. In the study, the effect of different collectors, flotation $\mathrm{pH}$ values, and mixed collector rates were investigated.

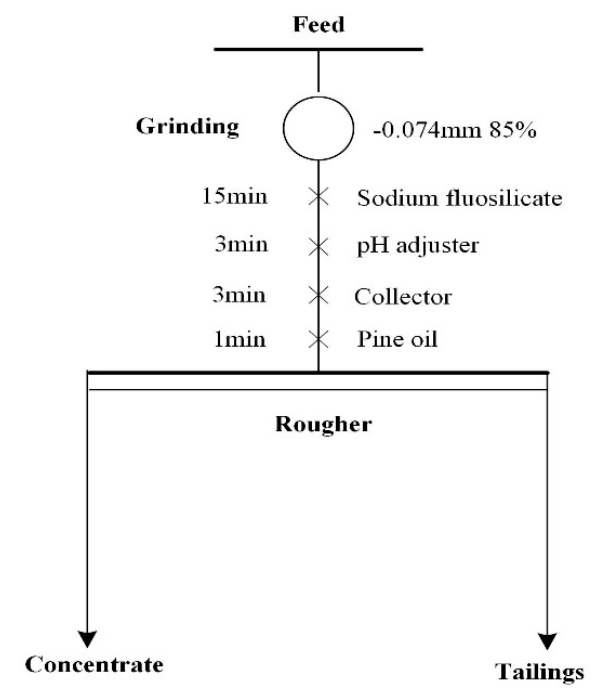

Figure 1. Flow sheet of flotation tests.

The concentrates and tailings from flotation after the filtering and drying were weighed and assayed, respectively. The experiments were repeated three times, and the average values were reported. The experimental error was found to be 3\%-5\%. The magnetite recovery of flotation concentrate was calculated by the following equation:

$$
\varepsilon_{\mathrm{m}}=\frac{\gamma \cdot\left(\beta_{1}-1.59 \beta_{2}\right)}{\beta_{0}-1.59 \beta_{3}}
$$

where $\varepsilon_{\mathrm{m}}$ is the magnetite recovery in concentrate, $\beta_{1}$ is the Fe grade of concentrate, $\beta_{2}$ is the $S$ grade of concentrate, $\beta_{0}$ is the Fe grade of raw ore, $\beta_{3}$ is the $S$ grade of raw ore, $\gamma$ is yield of concentrate, and the rate of $\mathrm{Fe}$ to $\mathrm{S}$ is 1.59 in pyrrhotite. The equation is a criterion for evaluating the loss of magnetite.

The desulfurization ratio of flotation process was calculated by the following equation:

$$
\mathrm{D}=1-\frac{\gamma \cdot \beta_{1}}{\beta_{0}}
$$


where $D$ is desulfurization ratio of flotation process, $\gamma$ is yield of concentrate, $\beta_{1}$ is the $S$ grade of concentrate, and $\beta_{0}$ is the $S$ grade of raw ore.

\subsubsection{Industrial Tests}

The industrial tests were performed in the Mineral Processing Plant at the Baotou iron Mine. The experimental system $\mathrm{S} 1$ used mixed collector $\left(\mathrm{m}_{\mathrm{NaBX}}: \mathrm{m}_{(\mathrm{BX})_{2}}=3: 2\right)$ as collector. The comparative system S2 was the original plant setup of the Baotou Plant, which used NaBX as collector in the flotation. Figure 2 shows the flotation circuit of industrial experiment in Baotou iron mine. The rougher and cleaner of the industrial experiment system are composed of 6 and 4 units of $40 \mathrm{~m}^{3}$ flotation cells, respectively. The scavenger consists of 4 units of $4 \mathrm{~m}^{3}$ flotation cells. The flotation conditions of industrial tests are also described in Figure 2. The processing capacities of S1 and S2 were 169.73 and $186.37 \mathrm{t} / \mathrm{h}$, respectively.

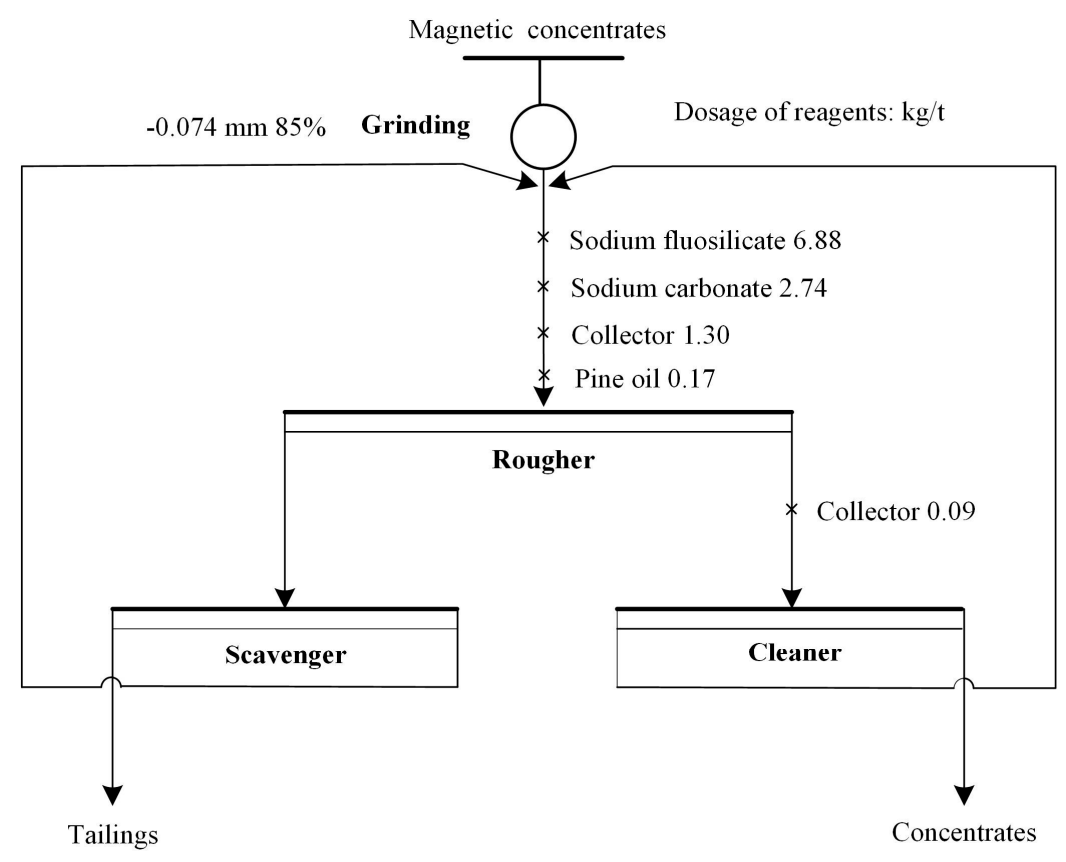

Figure 2. The flow sheet of industrial flotation in the Baotou iron Mine.

\subsubsection{Zeta Potential Measurements}

The zeta potentials of the minerals were measured using a ZetasizerNano ZS90 (Malvern, Worcestershire, UK). A suspension containing $0.01 \mathrm{wt} \%$ mineral particles ground to $-2 \mu \mathrm{m}$ in an agate mortar was prepared in the $\mathrm{KCl}$ solution $\left(10^{-3} \mathrm{M}\right)$. The measurements were conducted at room temperature $\left(25^{\circ} \mathrm{C}\right)$. The $\mathrm{pH}$ value of the suspension was adjusted to a desired value using $\mathrm{HCl}$ or $\mathrm{NaOH}$ solution. Besides, measurements were also carried out with the addition of collector at a constant concentration in the presence of sodium fluosilicate $\left(10^{-4} \mathrm{M}\right)$. The average zeta potential values of at least three independent measurements were recorded with a measurement error of $\pm 2 \mathrm{mV}$.

\subsubsection{FTIR Measurements}

Fourier Transform Infrared (FTIR) spectra ranging from 4000 to $400 \mathrm{~cm}^{-1}$ were used to characterize the collectors and their adsorption on the mineral surface at room temperature. The pure mineral samples were ground to less than $2 \mu \mathrm{m}$ before conditioned with the collectors $\left(10^{-3} \mathrm{M}\right)$. The mineral sample was reacted with collector in the presence of sodium fluosilicate $\left(10^{-4} \mathrm{M}\right)$. The pellets were prepared by mixing $\mathrm{KBr}$ and sample at the mass ratio of 200/1. The spectra of the samples were obtained with $\mathrm{KBr}$ pellets by a Fourier transform infrared spectrometer (Nicolet, WI, USA). 


\subsubsection{Contact Angle Measurements}

The contact angle were measured using Kruss K100 instrument (KRüSS, Hamburg, Germany). The pure mineral samples $(37-44 \mu \mathrm{m})$ were conditioned with collectors by laboratory flotation machine (1800 rpm) for $5 \mathrm{~min}$. The froth product from flotation after drying $\left(60^{\circ} \mathrm{C}\right)$ was pressed to round tablets $(\mathrm{d}=1 \mathrm{~cm})$. Finally, the contact angle measurements were performed. The measurements were repeated three times and the average values and standard deviations were reported.

\section{Results and Discussion}

\subsection{Flotation}

\subsubsection{Effect of Collector}

The flotation tests were conducted with individual collector $\mathrm{NaBX},(\mathrm{BX})_{2}$ and mixed collector $\left(\mathrm{m}_{\mathrm{NaBX}}: \mathrm{m}_{(\mathrm{BX})_{2}}=3: 2\right)$. The recovery-collector concentration curves of magnetite at $\mathrm{pH} 6$ are presented in Figure 3. It shows that the recovery of magnetite with $(B X)_{2}$ is independent of $(B X)_{2}$ concentration and the magnetite recovery changed in the range of $97.93 \%-98.24 \%$ in the studied concentration range. When using $\mathrm{NaBX}$ as collector, the recovery of magnetite is the lowest compared with the other two groups and decreased sharply with the increase of the collector concentration. In the case of $(\mathrm{BX})_{2} / \mathrm{NaBX}$, it is clear that the magnetite recovery of concentrate is higher than those of single collectors, meanwhile the magnetite recovery has little decrease with an increase of collector concentration. Figure 4 shows the desulfurization ratio of flotation performance as a function of collector concentration. For mixed collector system, the desulfurization ratio curve is similar to that of $\mathrm{NaBX}$, which is much higher than that of $(\mathrm{BX})_{2}$. It can be concluded that a high desulfurization ratio was achieved with little loss of magnetite when xanthate was mixed with dixanthogen as the collector, indicating that the mixed collector shows better selectivity than single collectors.

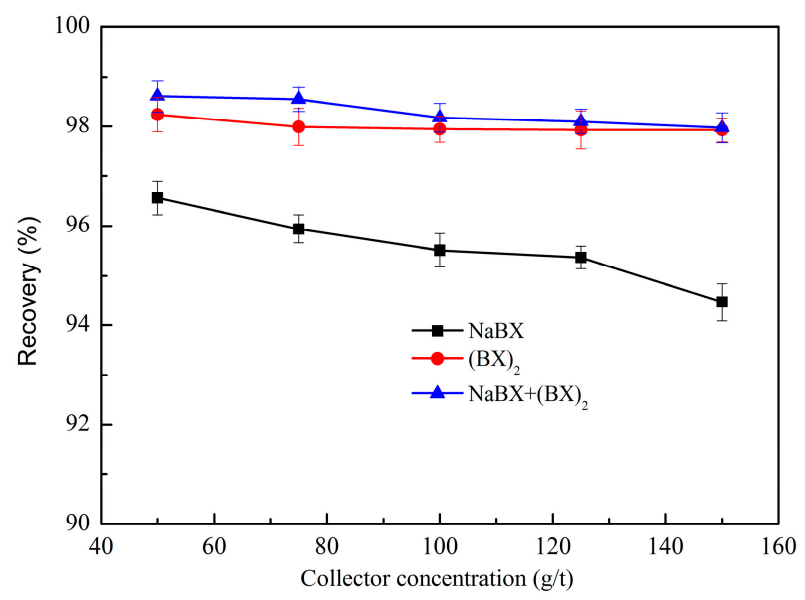

Figure 3. Flotation recoveries of magnetite with individual collector $\mathrm{NaBX},(\mathrm{BX})_{2}$ and mixed collector $\left(\mathrm{m}_{\mathrm{NaBX}}: \mathrm{m}_{(\mathrm{BX})_{2}}=3: 2\right)$ as a function of collector concentration $\left(\mathrm{NaSiF}_{6} 500 \mathrm{~g} / \mathrm{t}\right.$, pine oil $\left.46 \mathrm{~g} / \mathrm{t}, \mathrm{pH}=6\right)$.

The order of collector strength for the reagents used in this study has been reported to be $\mathrm{NaBX}>(\mathrm{BX})_{2}$ based on the chemical nature of the collector's group [15]. Results in this study match this order, as $\mathrm{NaBX}$ was found to have much better desulfurization performance when compared to $(\mathrm{BX})_{2}$. A possible explanation for this phenomenon is that $\mathrm{NaBX}$ is a stronger collector than $(\mathrm{BX})_{2}$. It has already been noted that the most significant decrease of magnetite recovery in flotation concentrate is when using $\mathrm{NaBX}$ compared to that of $(\mathrm{BX})_{2}$. A possible reason could be that the selectivity $(\mathrm{BX})_{2}$ is superior to $\mathrm{NaBX}$. It should be also noted that the mixed collector resulted in an overall enhancement in both magnetite recovery and desulfurization performance since each individual collector plays a 
different role on the flotation. In the mixed system, both the adsorption of $(\mathrm{BX})_{2}$ and $\mathrm{NaBX}$ collectors are enhanced due to co-adsorption. Adsorption of $\mathrm{NaBX}$ may be enhanced by the presence of $(\mathrm{BX})_{2}$ due to hydrophobic chain interactions and the reduction of electrostatic repulsion between ionic head groups of $\mathrm{NaBX}$ that are shield from each other by $(\mathrm{BX})_{2}$ molecules.

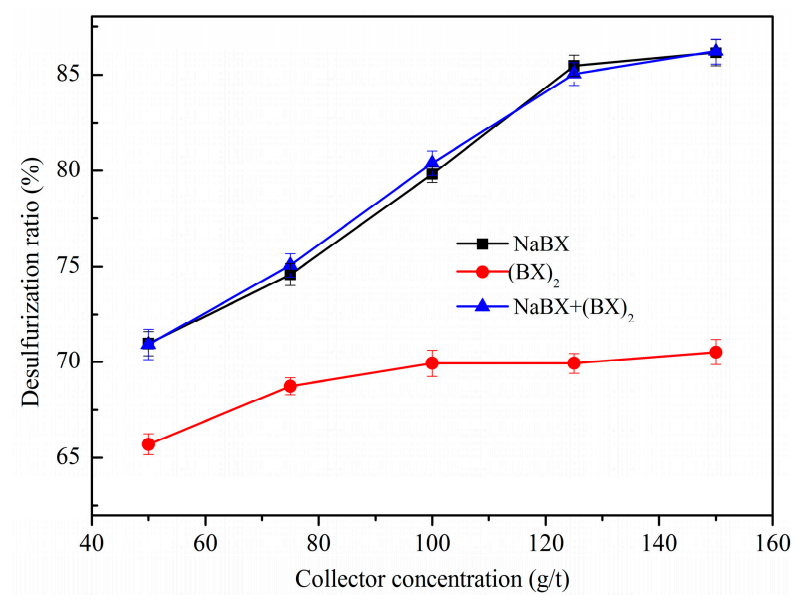

Figure 4. Desulfurization ratio of flotation performance with individual collector $\mathrm{NaBX},(\mathrm{BX})_{2}$ and mixed collector $\left(\mathrm{m}_{\mathrm{NaBX}}: \mathrm{m}_{(\mathrm{BX})_{2}}=3: 2\right)$ as a function of collector concentration $\left(\mathrm{NaSiF}_{6} 500 \mathrm{~g} / \mathrm{t}\right.$, pine oil $46 \mathrm{~g} / \mathrm{t}, \mathrm{pH}=6)$.

\subsubsection{Effect of Mixed Collector Ratio}

The flotation capacities of the $\mathrm{NaBX},(\mathrm{BX})_{2}$, and their mixture were investigated with batch flotation tests. It is important to take into account that the weight ratio of mixed collector $\left((\mathrm{BX})_{2} /\left[\mathrm{NaBX}+(\mathrm{BX})_{2}\right]\right)$ in pyrrhotite flotation tests. Figure 5 shows the flotation performances of mixed collectors with various $\alpha_{(\mathrm{BX})_{2}}$ at $\mathrm{pH}=6.0$. The results show that the magnetite recovery sharply increased with increasing $\alpha_{(\mathrm{BX})_{2}}$, reaching a maximum value $(98.11 \%)$ at $\alpha_{(\mathrm{BX})_{2}}=40 \%$ (the weight ratio of $(\mathrm{BX})_{2}: \mathrm{NaBX}=2: 3$ ). At $\alpha_{(\mathrm{BX})_{2}}>40 \%$, the magnetite recovery becomes slowly decrease. It also can be seen from Figure 5 that the desulfurization ratio of concentrate decreased slowly when the fraction of $(\mathrm{BX})_{2}$ increased from 0 to $40 \mathrm{wt} \%$ and thereafter the desulfurization ratio decreased significantly. There is a marked positive synergistic effect between $\mathrm{NaBX}$ and $(\mathrm{BX})_{2}$ on flotation of pyrrhotite. The mixed collector $(\mathrm{BX})_{2} / \mathrm{NaBX}$ is beneficial for the flotation of pyrrhotite, and the optimum weight ratio of $(\mathrm{BX})_{2}$ to $\mathrm{NaBX}$ is 2:3. Therefore, the mixed $(\mathrm{BX})_{2} / \mathrm{NaBX}$ with a weight ratio of 2:3 is selected for the following study.

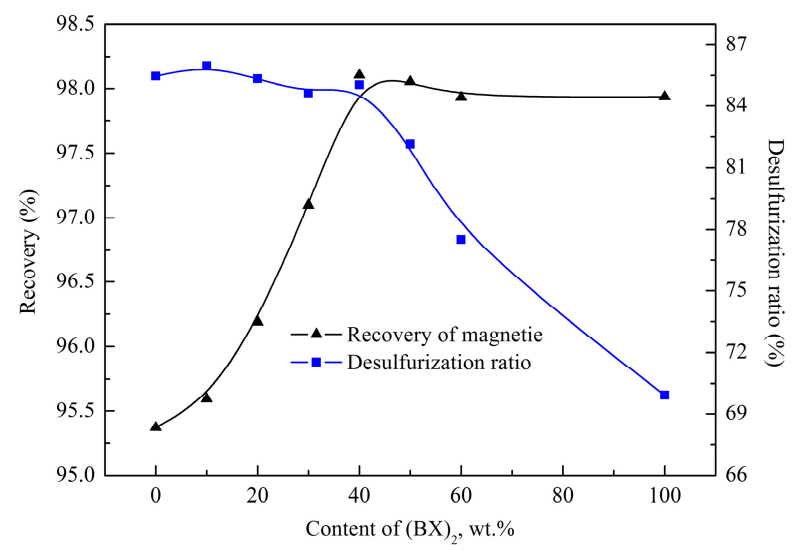

Figure 5. The magnetite recovery and desulfurization ratio in flotation concentrate with mixed collector at different combinations (mixed collector $125 \mathrm{~g} / \mathrm{t}, \mathrm{NaSiF}_{6} 500 \mathrm{~g} / \mathrm{t}$, pine oil $46 \mathrm{~g} / \mathrm{t}, \mathrm{pH}=6$ ). 


\subsubsection{Effect of the $\mathrm{pH}$ Value}

As we all know, the $\mathrm{pH}$ plays an important role in flotation system by controlling both mineral solubility and acid-base property of mineral pulp. Figure 6 shows the flotation response of magnetite recovery and desulfurization ratio as a function of $\mathrm{pH}$ with mixed collectors $\mathrm{NaBX} /(\mathrm{BX})_{2}$ $\left(\alpha_{(\mathrm{BX})_{2}}=40 \%\right)$. The results clearly indicate that, with mixed collector, the recovery of magnetite increased from $96.66 \%$ to $99.33 \%$ when the $\mathrm{pH}$ value increased from 5.0 to 8.0 . It also can be seen that the desulfurization ratio of flotation concentrate had little decrease with the increase of $\mathrm{pH}$ until around $\mathrm{pH} 6.0$ and thereafter the desulfurization ratio decreased dramatically, which indicated that pyrrhotite flotation is sensitive to $\mathrm{pH}$ value. Therefore, the maximum flotation response of pyrrhotite away from magnetite was attained with the mixed collector at $\mathrm{pH}$ around 6.

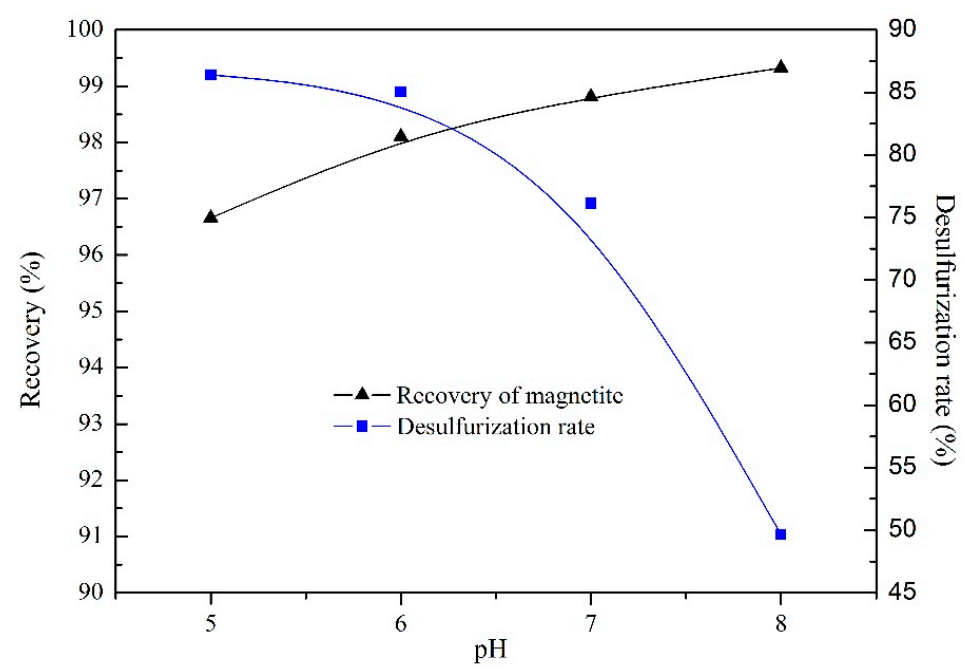

Figure 6. The magnetite recovery and desulfurization ratio in flotation concentrate as a function of $\mathrm{pH}$ with mixed collector $\left(\mathrm{NaBX} 75 \mathrm{~g} / \mathrm{t},(\mathrm{BX})_{2} 50 \mathrm{~g} / \mathrm{t}, \mathrm{NaSiF}_{6} 500 \mathrm{~g} / \mathrm{t}\right.$, pine oil $46 \mathrm{~g} / \mathrm{t}$ ).

It is well known that pyrrhotite is a reactive sulphide mineral and easy to be oxidized in alkaline solutions [16]. The general oxidation mechanisms may be described by the following reactions [17,18]. The formation of $\mathrm{Fe}(\mathrm{OH})_{3}$ precipitation on the surface of pyrrhotite decreases surface hydrophobicity of pyrrhotite and this is why the desulfurization ratio decreased as the $\mathrm{pH}$ increased. In addition, another possible reason could be that the synergetic effect was poor since part of dixanthogen may transform into xanthate in an alkaline environment.

$$
\begin{gathered}
\mathrm{Fe}_{1-x} \mathrm{~S}_{\mathrm{s}}+\left(2-\frac{1}{2} x\right) \mathrm{O}_{2}+x \mathrm{H}_{2} \mathrm{O} \rightarrow(1-x) \mathrm{Fe}^{2+}+\mathrm{SO}_{4}^{2-}+2 x \mathrm{H}^{+} \\
\mathrm{Fe}^{2+}+\frac{1}{4} \mathrm{O}_{2}+\mathrm{H}^{+} \rightarrow \mathrm{Fe}^{3+}+\frac{1}{2} \mathrm{H}_{2} \mathrm{O} \\
\mathrm{Fe}^{3+}+3 \mathrm{H}_{2} \mathrm{O} \rightarrow \mathrm{Fe}(\mathrm{OH})_{3}+3 \mathrm{H}^{+}
\end{gathered}
$$

\subsection{Industrial Tests}

Because of the good effect of mixed $\mathrm{NaBX} /(\mathrm{BX})_{2}$ for pyrrhotite flotation, the mixed collector $\left(\mathrm{m}_{\mathrm{NaBX}}: \mathrm{m}_{(\mathrm{BX})_{2}}=3: 2\right)$ was selected in the industrial tests performed in the Mineral Processing Plant of the Baotou iron Mine. The flotation flowsheet and flotation conditions are listed in Figure 2, and the flotation results are shown in Table 5. It can be seen from the results that the grade and recovery of iron increased significantly when the industrial tests were performed in the S1 system, which indicates that mixed collector had a good selectivity on the flotation of pyrrhotite while having 
a similar desulfurization capacity in comparison with the system S2. Since the industrial tests, mixed collector has been commercially used in the Baotou iron Mine.

Table 5. The results of industrial flotation tests on September.

\begin{tabular}{ccccccc}
\hline \multirow{2}{*}{ System } & \multirow{2}{*}{ Products } & Yield (wt \%) & \multicolumn{2}{c}{ Grades (\%) } & \multicolumn{2}{c}{ Recoveries (\%) } \\
\cline { 4 - 7 } & & & Fe & S & Fe & S \\
\hline \multirow{3}{*}{ S1 Mixed collector } & Concentrates & 91.23 & 69.25 & 0.43 & 92.50 & 19.62 \\
& Tailings & 8.77 & 58.42 & 18.75 & 7.50 & 80.38 \\
& Feed & 100.00 & 68.30 & 2.05 & 100.00 & 100.00 \\
\hline \multirow{2}{*}{ S2 NaBX } & Concentrates & 88.92 & 69.13 & 0.44 & 90.24 & 19.32 \\
& Tailings & 11.08 & 60.01 & 14.75 & 9.76 & 80.68 \\
& Feed & 100.00 & 68.12 & 2.03 & 100.00 & 100.00 \\
\hline
\end{tabular}

\subsection{Zeta-Potential Measurements}

Zeta potentials of pyrrhotite in the absence and presence of $\mathrm{NaBX},(\mathrm{BX})_{2}$ and their mixture as a function of $\mathrm{pH}$ are illustrated in Figure 7. The results show that the zeta potential of pyrrhotite in distilled water decreased with the increase of the $\mathrm{pH}$, and the isoelectric point of pyrrhotite was about 8.6 in distilled water, which is in agreement with the results obtained by other researchers [19]. The zeta potential with dixanthogen when used alone appeared to be similar at the $\mathrm{pH}$ range between 2 and 12. It indicated that dixanthogen had a little effect on the zeta potential at all studied pH values. This could be attributed to low ionizability of dixanthogen or low adsorption of the desired collector on the pyrrhotite surface. In the presence of $\mathrm{NaBX}$, the zeta potential decreased significantly and the isoelectric point changed from 8.6 to about 4.5. It indicated that the anionic collector adsorbed onto the pyrrhotite surface by chemical bonding. In the presence of mixed $\mathrm{NaBX} /(\mathrm{BX})_{2}$, the zeta potentials were more positive than that in the presence of $\mathrm{NaBX}$ alone, but more negative when compared to $(\mathrm{BX})_{2}$ alone. This might be explained by the fact that dixanthogen, a neutral and strongly hydrophobic collector, adsorbed on the pyrrhotite surface as a co-collector [14].

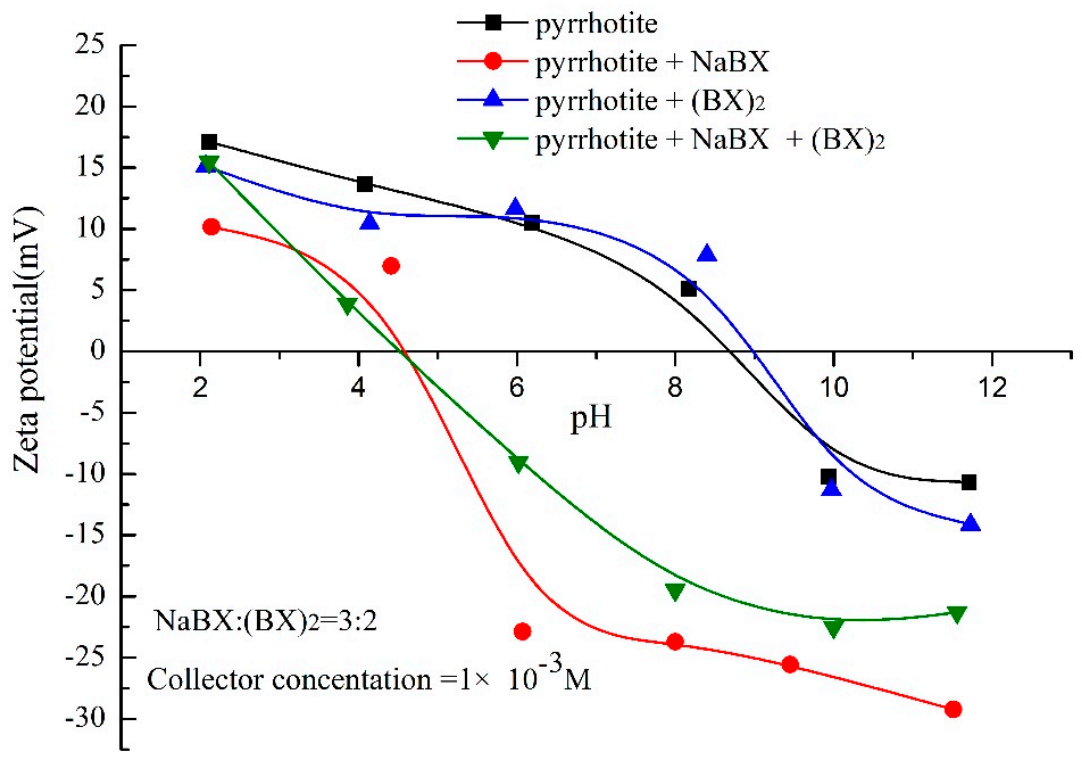

Figure 7. The zeta potential of pyrrhotite in the absence and presence of $\mathrm{NaBX},(\mathrm{BX})_{2}$, and their mixture as a function of $\mathrm{pH}$ value, respectively.

It can be seen in Figure 8 that the zeta potential of magnetite in distilled water decreased with the increase of the $\mathrm{pH}$, and the isoelectric point of magnetite was about 6.5 in distilled water. 
When magnetite interacts with $\mathrm{NaBX},(\mathrm{BX})_{2}$, and their mixture respectively, zeta-potential values are very close to that in water. Thereby, it may be concluded that no significant $\mathrm{NaBX},(\mathrm{BX})_{2}$, and their mixture are adsorbed on magnetite.

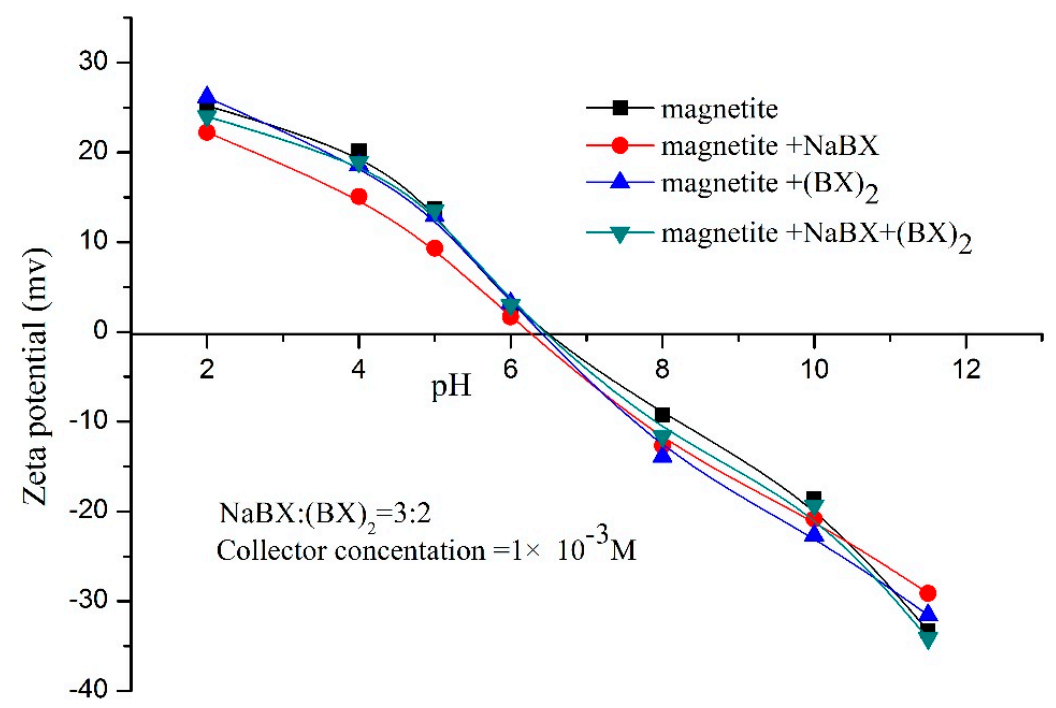

Figure 8. The zeta potential of magnetite in the absence and presence of $\mathrm{NaBX},(\mathrm{BX})_{2}$, and their mixture as a function of $\mathrm{pH}$ value, respectively.

\subsection{FTIR Analysis}

In order to investigate the adsorption mechanism of $\mathrm{NaBX},(\mathrm{BX})_{2}$, and their mixture on the mineral surfaces, the collectors, minerals, and minerals after reacting with collectors were characterized by infrared spectrometry at $298 \mathrm{~K}$. The IR spectra of $\mathrm{NaBX}$ and $(\mathrm{BX})_{2}$ are shown in Figures 9 and 10, respectively. The spectra are given for the region $600-1600 \mathrm{~cm}^{-1}$ where all the absorption bands are characteristic of the $\mathrm{NaBX}$ and $(\mathrm{BX})_{2}$ polar groups. The characteristic IR spectral peaks of these collectors are very similar to that gained by other researcher [20]. In Figure 9, the characteristic peaks at 1168.92 and $1191.95 \mathrm{~cm}^{-1}$ arise from asymmetric stretching vibration of $\mathrm{C}-\mathrm{O}-\mathrm{C}$ in NaBX. The peak frequency at $1111.20 \mathrm{~cm}^{-1}$ originates from symmetric stretching vibration of $\mathrm{C}-\mathrm{O}-\mathrm{C}$ in $\mathrm{NaBX}$. The peak at $1062.06 \mathrm{~cm}^{-1}$ is assigned to the stretching vibration of the $\mathrm{C}=\mathrm{S}$ group of $\mathrm{NaBX}$.

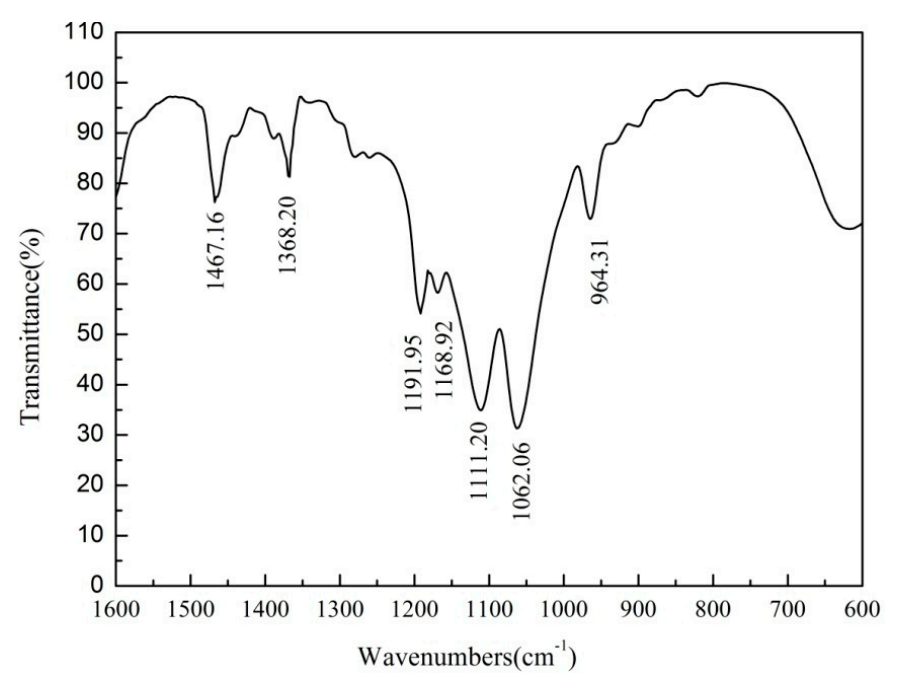

Figure 9. FTIR spectrum of sodium butyl xanthate. 


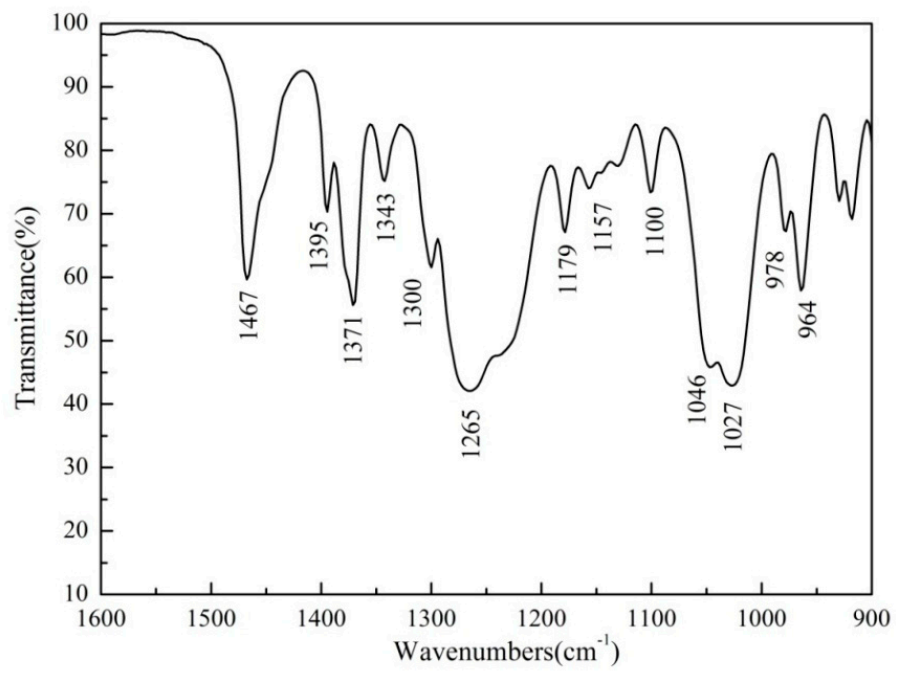

Figure 10. FTIR spectrum of dibutyl dixanthogen.

In Figure 10, the IR spectrum of $(\mathrm{BX})_{2}$ contains intensive symmetric stretching vibration of $\mathrm{C}-\mathrm{O}-\mathrm{C}$ with peak frequencies at 1157 and $1179 \mathrm{~cm}^{-1}$. The peak at $1265 \mathrm{~cm}^{-1}$ is assigned to the asymmetric stretching vibration of $\mathrm{C}-\mathrm{O}-\mathrm{C}$ in $(\mathrm{BX})_{2}$. The characteristics peak at $1027 \mathrm{~cm}^{-1}$ is attributed to stretching vibration of $\mathrm{C}=\mathrm{S}$ in $(\mathrm{BX})_{2}$. It can be seen that stretching vibration frequencies of $\mathrm{C}-\mathrm{O}-\mathrm{C}$ in $(\mathrm{BX})_{2}$ shift toward higher frequencies when the vibration frequency of $\mathrm{C}=\mathrm{S}$ shifts toward lower frequencies compared to that of $\mathrm{NaBX}$. The same trend can be found in previous research [21,22].

The FTIR spectrum of pyrrhotite after reacting with $\mathrm{NaBX}$ is shown in Figure 11. The peak at $1048 \mathrm{~cm}^{-1}$ is assigned to $\mathrm{C}=\mathrm{S}$ stretching vibration of $\mathrm{Fe}(\mathrm{BX})_{3}$. The weak bond at $1117.39 \mathrm{~cm}^{-1}$ is attributed to stretching vibration of $\mathrm{C}-\mathrm{O}-\mathrm{C}$ in $\mathrm{Fe}(\mathrm{BX})_{3}$. None of the characteristics peak of $(\mathrm{BX})_{2}$ can be seen in Figure 11.

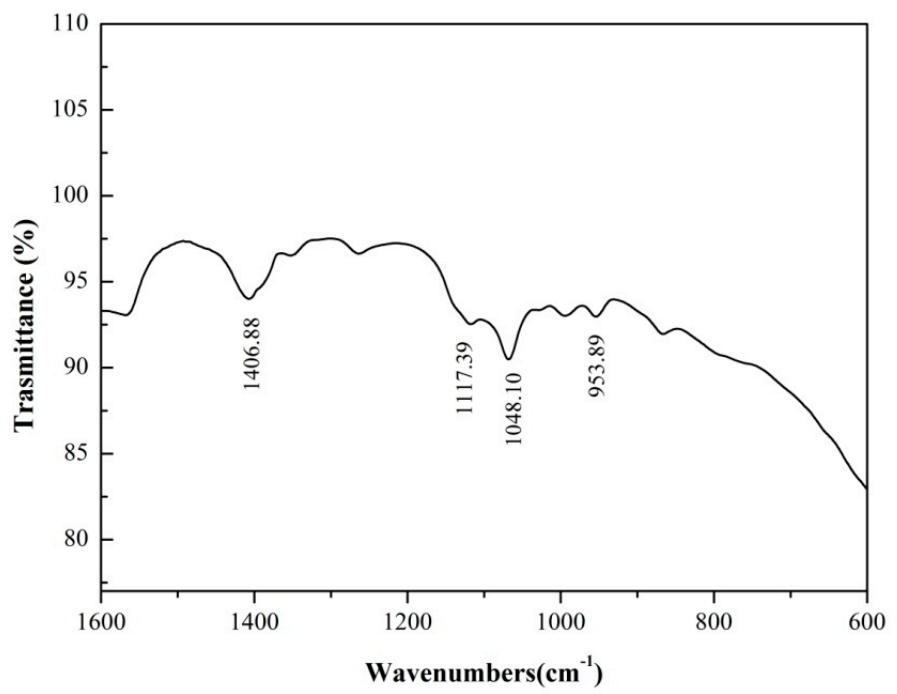

Figure 11. FTIR spectra of pyrrhotite after reacting with $\mathrm{NaBX}$ at $\mathrm{pH}=6$.

The FTIR spectrum of pyrrhotite after reacting with mixed collector $\left(\mathrm{m}_{\mathrm{NaBX}}: \mathrm{m}_{(\mathrm{BX})_{2}}=3: 2\right)$ is shown in Figure 12. After the interaction with the mixed collector, both the characteristic IR spectral peaks of $\mathrm{Fe}(\mathrm{BX})_{3}$ and $(\mathrm{BX})_{2}$ can be observed on the mineral surface. The stronger characteristic peaks at 1029.01 and $1262.67 \mathrm{~cm}^{-1}$ could be identified as the stretching vibration of $C=S$ in xanthate and the $\mathrm{C}-\mathrm{O}-\mathrm{C}$ stretching vibration of $(\mathrm{BX})_{2}$, respectively $[22,23]$. The weaker peaks at 1102.15 and 
$1131.90 \mathrm{~cm}^{-1}$ are assigned to the stretching vibration of $\mathrm{C}-\mathrm{O}-\mathrm{C}$ in xanthate. It can be found that the $\mathrm{C}=\mathrm{S}$ stretching vibration of xanthate iron shifts toward to lower frequency compared to that of $\mathrm{NaBX}$. The results indicate that the xanthate and dixanthogen molecules are bound directly to the pyrrhotite surface.

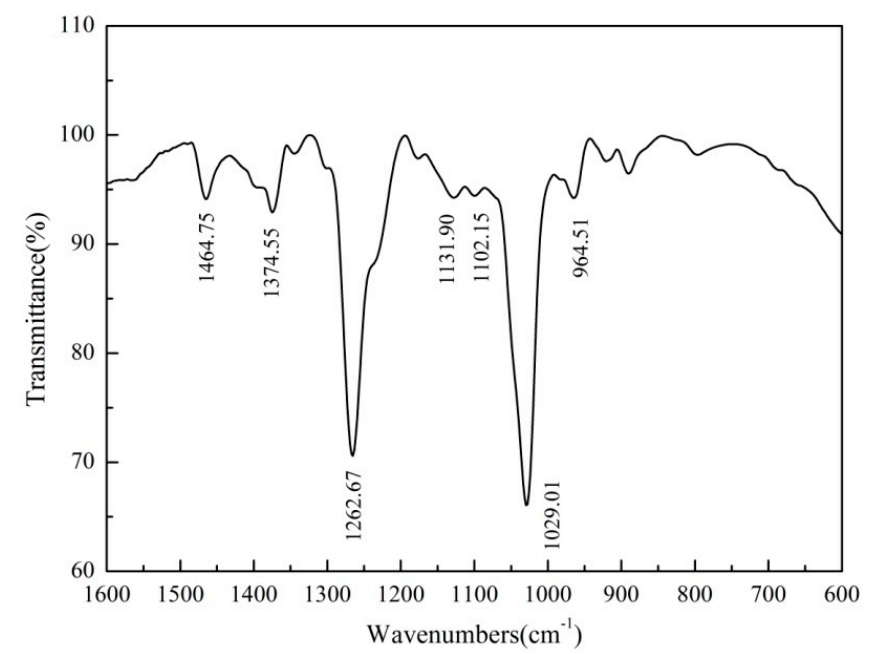

Figure 12. FTIR spectra of pyrrhotite after reacting with mixed collector $\left(\mathrm{NaBX}+(\mathrm{BX})_{2}\right)$ at $\mathrm{pH}=6$.

\subsection{Wetting Characteristic of Pyrrhotite wih Mixed Collectors}

The wettability nature of mixed $(\mathrm{BX})_{2} / \mathrm{NaBX}$ collectors on pyrrhotite and thereby synergistic effect between $(\mathrm{BX})_{2}$ and $\mathrm{NaBX}$ on solid/liquid interface were investigated by contact angle measurement. Figure 13 presents the contact angle of pyrrhotite as a function of $\alpha_{(\mathrm{BX})_{2}}$. It can be seen that there is an increase in the contact angles of pyrrhotite when $(\mathrm{BX})_{2}$ is added to an $\mathrm{NaBX}$ in the low $\alpha_{(\mathrm{BX})_{2}}$ range, and the contact angle reaches the maximum value, improving up to about $70^{\circ}$ when $\alpha_{(\mathrm{BX})_{2}}$ is $45 \%$. In other words, combined use of the reagents strengthens the hydrophobicity of pyrrhotite surface and produces greater contact angles. This phenomenon has been discovered previously by $\mathrm{Xu}$ [24]. It is because that the hydrophobicity of $(\mathrm{BX})_{2}$ is greater than $\mathrm{NaBX}$, and the $\mathrm{NaBX}$ could increase the solubility of $(\mathrm{BX})_{2}$ at the same time. However, as the $\alpha_{(\mathrm{BX})_{2}}$ further increases, the contact angle of pyrrhoite decreases. The reason could be explained by low solubility of $(\mathrm{BX})_{2}$.

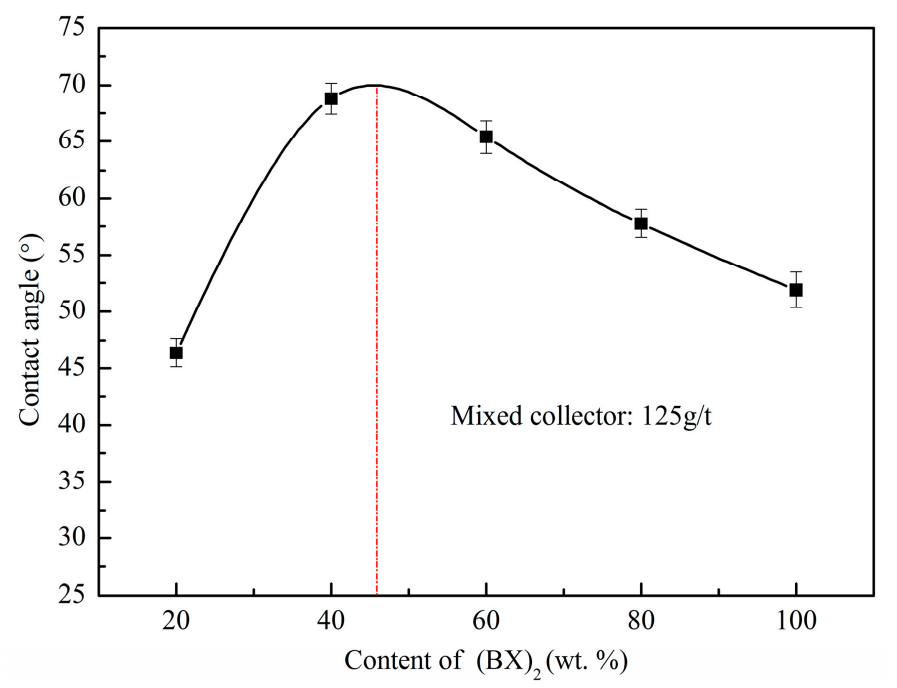

Figure 13. Contact angle vs. mass fraction of $(\mathrm{BX})_{2}$ for pyrrhotite with mixed collectors at $\mathrm{pH}$ 6.0. 


\section{Conclusions}

The synergetic effect of mixed collector systems of $(\mathrm{BX})_{2}$ and $\mathrm{NaBX}$ was investigated by flotation tests. The separation effect between pyrrhotite and magnetite was dramatically enhanced in terms of both magnetite recovery and desulfurization ratio. The ideal composition of the mixed collector was determined by batch flotation tests to be $40 \mathrm{wt} \%(\mathrm{BX})_{2}$ and $60 \mathrm{wt} \% \mathrm{NaBX}$ for pyrrhotite flotation. A reasonable $\mathrm{pH}$ value for application of the collector mixture was determined to be around 6.0.

The zeta potential experiments indicated that chemical adsorption occurred on the pyrrhotite surface. The FTIR analysis showed that the groups of $\mathrm{NaBX}$ and $(\mathrm{BX})_{2}$ participated in the chemical reaction. The contact angle results indicated there was a synergistic effect of mixed $(\mathrm{BX})_{2}$ and $\mathrm{NaBX}$ collectors at the solid-liquid interface. In the mixed systems, dixanthogen associated with xanthate, enhancing hydrophobicity of pyrrhotite due to co-adsorption.

Acknowledgments: The authors acknowledge the support of the National Natural Science Foundation of China (Grant Nos. 51574188).

Author Contributions: Yingyong Ge conceived and designed the experiments; the experiments, analysis of data and article writing are carried out by Jun $\mathrm{Yu}$; Xinwei Cai performed a part of experiments.

Conflicts of Interest: The authors declare no conflict of interest.

\section{References}

1. Yu, Y.F. Processing state and technology progress of iron ore in China. Conserv. Util. Miner. Process 2005, 6, 43-46.

2. Yu, K.-P.; Yu, Y.-F.; Xu, X.-Y. Separation behavior and mechanism of hematite and collophane in the presence of collector RFP-138. Trans. Nonferr. Metals Soc. China 2013, 23, 501-507. [CrossRef]

3. Liu, X.H.; Liao, Z.H.; Yan, X.H.; Chen, W. Comprehensive recovery of magnetite and pyrrhotite from a low-grade iron ore. Min. Metall. Eng. 2014, 34, 47-51.

4. Arvidson, B.; Klemetti, M.; Knuutinen, T.; Kuusisto, M.; Man, Y.T.; Hughes-Narborough, C. Flotation of pyrrhotite to produce magnetite concentrates with a sulphur level below $0.05 \% w / w$. Miner. Eng. 2013, 50, 4-12. [CrossRef]

5. Allison, S.A.; O'Connor, C.T. An investigation into the flotation behaviour of pyrrhotite. Int. J. Miner. Process. 2011, 98, 202-207. [CrossRef]

6. Lotter, N.O.; Bradshaw, D.J. The formulation and use of mixed collectors in sulphide flotation. Miner. Eng. 2010, 23, 945-951. [CrossRef]

7. Vidyadhar, A.; Kumari, N.; Bhagat, R.P. Adsorption mechanism of mixed collector systems on hematite flotation. Miner. Eng. 2012, 26, 102-104. [CrossRef]

8. Cao, Q.; Cheng, J.; Wen, S.; Li, C.; Bai, S.; Liu, D. A mixed collector system for phosphate flotation. Miner. Eng. 2015, 78, 114-121. [CrossRef]

9. Rao, K.; Dwari, R.; Lu, S.; Vilinska, A.; Somasundaran, P. Mixed Anionic/Non-Ionic Collectors in Phosphate Gangue Flotation from Magnetite Fines. Open Miner. Process. J. 2011, 4, 14-24. [CrossRef]

10. Rao, K.H.; Forssberg, K.S.E. Mixed collector systems in flotation. Int. J. Miner. Process. 1997, 51, 67-79.

11. Gao, Z.; Bai, D.; Sun, W.; Cao, X.; Hu, Y. Selective flotation of scheelite from calcite and fluorite using a collector mixture. Miner. Eng. 2015, 72, 23-26. [CrossRef]

12. Filippova, I.V.; Filippov, L.O.; Duverger, A.; Severov, V.V. Synergetic effect of a mixture of anionic and nonionic reagents: Ca mineral contrast separation by flotation at neutral pH. Miner. Eng. 2014, 66-68, 135-144. [CrossRef]

13. Xu, L.; Wu, H.; Dong, F.; Wang, L.; Wang, Z.; Xiao, J. Flotation and adsorption of mixed cationic/anionic collectors on muscovite mica. Miner. Eng. 2013, 41, 41-45. [CrossRef]

14. Ejtemaei, M.; Irannajad, M.; Gharabaghi, M. Influence of important factors on flotation of zinc oxide mineral using cationic, anionic and mixed (cationic/anionic) collectors. Miner. Eng. 2011, 24, 1402-1408. [CrossRef]

15. Ding, D.H.; Long, X.Y.; Wang, D.Z. Mechanism of pyrite oxidation and flotation. Nonferr. Metals 1993, 45, 24-29. 
16. Miller, J.D.; Li, J.; Davidtz, J.C.; Vos, F. A review of pyrrhotite flotation chemistry in the processing of PGM ores. Miner. Eng. 2005, 18, 855-865. [CrossRef]

17. Bunkholt, I.; Kleiv, R.A. Pyrrhotite oxidation and its influence on alkaline amine flotation. Miner. Eng. 2015, 71, 65-72. [CrossRef]

18. Chen, X.; Peng, Y. The effect of regrind mills on the separation of chalcopyrite from pyrite in cleaner flotation. Miner. Eng. 2015, 83, 33-43. [CrossRef]

19. Hong, Q.Y.; Tang, Y.H.; Wang, Y.H. Investigation on properties and structure of pyrrhotite and the different of its floatability. Metal Mine 2011, 415, 64-67.

20. Zhang, Y.; Cao, Z.; Cao, Y.; Sun, C. FTIR studies of xanthate adsorption on chalcopyrite, pentlandite and pyrite surfaces. J. Mol. Struct. 2013, 1048, 434-440. [CrossRef]

21. Bulut, G.; Atak, S. Role of dixanthogen on pyrite flotation: Solubility, adsorption studies and Eh, FTIR measurements. Miner. Metall. Process. 2002, 19, 81-86.

22. Zhang, Q.; Hu, Y.H.; Gu, G.H.; Xu, J. The study on the interaction between ethyl xanthate and pyrrhotitein electrochemical flotation by FTIR spectroscopy. Min. Metall. Eng. 2004, 24, 42-44.

23. Mustafa, S.; Hamid, A.; Naeem, A. Xanthate adsorption studies on chalcopyrite ore. Int. J. Miner. Process. 2004, 74, 317-325. [CrossRef]

24. Xu, L.; Hu, Y.; Tian, J.; Wu, H.; Wang, L.; Yang, Y.; Wang, Z. Synergistic effect of mixed cationic/anionic collectors on flotation and adsorption of muscovite. Colloids Surf. A Physicochem. Eng. Asp. 2016, 492, 181-189. [CrossRef]

(C) 2016 by the authors; licensee MDPI, Basel, Switzerland. This article is an open access article distributed under the terms and conditions of the Creative Commons Attribution (CC-BY) license (http://creativecommons.org/licenses/by/4.0/). 